\title{
LIETUVOS AUKŠTŲJŲ MOKYKLŲ STUDENTŲ FIZINIS AKTYVUMAS IR JI LEMIANTYS VEIKSNIAI
}

\author{
Marius Baranauskas ${ }^{1}$, Rokas Arlauskas ${ }^{2}$, Rimantas Stukas ${ }^{2}$, Jonas Algis Abaravičius ${ }^{1}$, \\ Toma Martinkutè ${ }^{2}$ \\ ${ }^{1}$ Vilniaus universiteto Medicinos fakulteto Biomedicinos mokslu instituto \\ Fiziologijos, biochemijos ir laboratorinès medicinos katedra, \\ ${ }^{2}$ Vilniaus universiteto Medicinos fakulteto Sveikatos moksly instituto Visuomenès sveikatos katedra
}

Raktažodžiai: studentai, fizinis aktyvumas, kūno masės indeksas, visuomenès sveikata.

\begin{abstract}
Santrauka
Tarptautiniu lygiu išaiškintos geros sveikatos ir pakankamo fizinio aktyvumo sąsajos yra nenuginčijamos. Dẻl nepakankamo fizinio aktyvumo, nutukimo, gyvenimo trukmé gali sutrumpèti, daugèti lètinių susirgimų, todèl būtina nuolatinè fizinio aktyvumo stebėsena. Tyrimo tikslas - nustatyti studentų kūno masès indeksą, fizinį aktyvumą ir jị lemiančius veiksnius. Vykdant tyrimą, buvo apklausti 278 studentai.

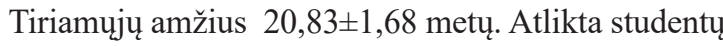
apklausa, panaudojant anketinès apklausos metodą. Tyrimo rezultatai parodè, kad antsvoris būdingas kas dešimtam studentui (vyrui), o nepakankama kūno masé - kas dešimtai studentei (moteriai). Esminis sportuojančių studentų tikslas yra sveikatos gerinimas, tačiau 48,7 proc. fizinis aktyvumas yra nepakankamas (<150 min per savaitę). Nepakankamą studentų fizinį aktyvumą dažniausiai lemia laiko trūkumas. I nepakankamo fizinio aktyvumo grupę patenka Vilniaus universiteto studentès (moterys). Didžioji dalis $(64,9$ proc.) studentų sportuoja uždarose patalpose (sporto salèse, klubuose), bet per retai fizine veikla užsiima lauke, gryname ore. Perspektyvoje būtų racionalu ị paskaitų tvarkaraščius įtraukti privalomąsias kūno kultūros pratybas, ugdyti studentų sveikos gyvensenos ịūdžius ir didinti motyvaciją užsiimti aktyvia fizine veikla.
\end{abstract}

\section{Ivadas}

Tarptautiniu, ar nacionaliniu lygiu išaiškintos geros sveikatos ir pakankamo fizinio aktyvumo sąsajos - nenuginčija- mos [6-8]. Kitu atveju, dèl nepakankamo fizinio aktyvumo, nutukimo, gyvenimo trukmè gali sutrumpèti, daugèti lètinių susirgimų [1,2].

Pasaulio sveikatos organizacija (toliau - PSO) rekomenduoja aerobini pajėgumą ugdančia vidutinio intensyvumo fizine veikla užsiimti ne mažiau nei 150 min per savaitę [3]. Tyrimų duomenimis, Klaipėdoje beveik pusès studentų fizinis aktyvumas yra mažesnis, nei PSO rekomenduojamas [4]. Vilniuje šis skaičius sudaro 54,7 procento. [5]. Analogiškus nepakankamo studentų fizinio aktyvumo duomenis patvirtina tyrimų rezultatai, gauti Ispanijos [6], Italijos [7], Vengrijos [8], Kroatijos [9], Mičigano (JAV) [10], Saudo Arabijos [11, 12] universitetuose.

Nustatyta, kad dèl didelio mokymosi krūvio studentai priversti didžiają laiko dalị sèdèti, jiems trūksta laiko ir motyvacijos sportuoti, todèl beveik pusè jų yra nepakankamai fiziškai aktyvūs $[4,13]$. Organizuota fizinè veikla ị studentų paskaitų tvarkaraščius yra nepakankamo lygio [14]. Nesant moksliškai pagrịsto atsakymo, kodèl, nepaisant žinojimo apie pakankamo fizinio aktyvumo naudą, didelè dalis žmonių yra per mažai fiziškai aktyvūs [15], būtina nuolatinè fizinio aktyvumo stebėsena, esamosios situacijos analizè, kad būtu galima veiksmingiau planuoti ir igyvendinti studentų mitybą ir fizinį aktyvumą optimizuojančias priemones.

Tyrimo tikslas - nustatyti Vilniaus universiteto Medicinos fakulteto bei Lietuvos edukologijos universiteto Sporto ir sveikatos fakulteto studentų kūno masès indeksą, fizini aktyvumą ir jị lemiančius veiksnius.

\section{Tyrimo objektas ir metodika}

Tikslinę tyrimo populiaciją sudare Vilniaus universiteto (toliau - VU) Medicinos fakulteto ir Lietuvos edukologijos universiteto (toliau - LEU) Sporto ir sveikatos fakulteto bakalauro nuolatinių studijų 
programų I-IV kursų studentai. Studentų skaičius gautas įvertinus aktualius universitetuose studijuojančių studentų sąrašus $(2018 \mathrm{~m}$. lapkričio 3 d. duomenimis). Iš viso buvo apklausti VU 193, LEU - 85 studentai.

Siekiant ịvertinti Lietuvos aukštujjų mokyklų studentų fizinį aktyvumą, buvo vykdoma studentų apklausa, panaudojant anketinès apklausos metodą, tiesioginio anketavimo būdu, paskaitų metu, atitinkamuose universitetuose. Tyrimo anketą sudare dviejų (uždaro ir atviro) tipų klausimai. Iš viso buvo pateikiami 25 klausimai, suskirstyti į 2 grupes. Pirmosios grupès klausimus sudarè studentų sociodemografiniai duomenys (lytis, amžius, svoris, ūgis, aukštoji mokykla). Pagal pateiktus kūno svorio ir ūgio duomenis, buvo apskaičiuojamas kūno masès indeksas (toliau - KMI), pagal kurị studentai suskirstyti į tris grupes: per mažo kūno svorio $\left(\mathrm{KMI}<18,5 \mathrm{~kg} / \mathrm{m}^{2}\right)$, normalaus svorio $\left(\mathrm{KMI} 18,5-24,99 \mathrm{~kg} / \mathrm{m}^{2}\right)$, turintys antsvorio $(\mathrm{KMI} \geq 25)$ [16].

Antroje klausimų grupeje studentų fizinis aktyvumas buvo vertinamas pagal Lietuvos Respublikos sveikatos apsaugos ministro 2016 m. birželio 23 d. įsakymą Nr. V-836 „Dèl Lietuvos Respublikos sveikatos apsaugos ministro 1999 m. lapkričio 25 d. ịsakymo Nr. 510 „Dèl rekomenduojamų paros maistinių medžiagų ir energijos normų patvirtinimo" pakeitimo" sudarytas fizinio aktyvumo grupes:

I grupè - labai lengvas ir lengvas darbas (namų tvarkymas, vaikščiojimas);

II grupe - vidutinio sunkumo darbas (namų tvarkymas, vaikščiojimas ir 30-60 min trukmès vidutinio intensyvumo fizinis krūvis, pavyzdžiui, greitas ejjimas $5-7 \mathrm{~km} / \mathrm{val}$. greičiu);

III grupè - sunkus darbas (namų tvarkymas, vaikščiojimas ir ne mažesnès nei 60 min trukmès vidutinio intensyvumo fizinis krūvis, pavyzdžiui, greitas ejjimas 5-7 km/val. greičiu);

IV grupe - labai sunkus darbas (namų tvarkymas, vaikščiojimas plius ne

1 lentelè. Sporto šakų klasifikacija pagal energijos gamybos organizme ypatumus treniruočių metu

\begin{tabular}{|c|c|c|}
\hline Sporto šakos & $\begin{array}{l}\text { Fizinio } \\
\text { darbo } \\
\text { trukmé }\end{array}$ & $\begin{array}{l}\text { Energijos gamybos organizme } \\
\text { ypatumai fizinio krūvio metu }\end{array}$ \\
\hline $\begin{array}{l}\text { Greitumą ir jėgą ugdančios sporto } \\
\text { šakos } \\
\text { (sunkioji atletika, svorių kilnojimas, } \\
\text { tempimo, jègos pratimai, tenisas, tin- } \\
\text { klinis, aerobika, aikido, atsispaudimai, } \\
\text { badmintonas, trumpų nuotolių bėgimas, } \\
\text { boulingas, fitnesas, futbolas, gimnas- } \\
\text { tika, imtynės, karate, krepšinis) }\end{array}$ & $\begin{array}{l}0,25 \text { sek. - } \\
120 \text { sek. }\end{array}$ & $\begin{array}{l}\text { Energija gaminama iš kreatinfos- } \\
\text { fato ir glikolizės reakcijų metu ne- } \\
\text { naudojant deguonies. }\end{array}$ \\
\hline $\begin{array}{l}\text { Aerobinị ir anaerobinị pajègumą ug- } \\
\text { dančios sporto šakos } \\
\text { (šokiai, vidutinių nuotolių bėgimas, } \\
\text { boksas, sportinė gimnastika, baidarių } \\
\text { ir kanojų irklavimas) }\end{array}$ & $\begin{array}{l}2 \mathrm{~min} .- \\
8 \mathrm{~min} .\end{array}$ & $\begin{array}{l}\text { Energija gaminama anaerobinès } \\
\text { ir aerobinės glikolizės reakcijų } \\
\text { metu. Dirbant trumpai, didžioji } \\
\text { dalis energijos gaminama anae- } \\
\text { robinès glikolizès reakcijų metu, } \\
\text { dirbant ilgiau - aerobinės gliko- } \\
\text { lizès reakcijų metu. }\end{array}$ \\
\hline $\begin{array}{l}\text { Aerobinị pajègumą ugdančios sporto } \\
\text { šakos } \\
\text { (irklavimas, ilgų nuotolių bėgimas, } \\
\text { plaukimas, triatlonas) }\end{array}$ & $\begin{array}{l}10 \mathrm{~min} .- \\
1,5 \mathrm{val} .\end{array}$ & $\begin{array}{l}\text { Didžioji dalis energijos gaminama } \\
\text { aerobinių reakcijų metu. Ilgèjant } \\
\text { fizinio darbo trukmei, energijos } \\
\text { gamybai naudojami riebalai ir } \\
\text { baltymai. }\end{array}$ \\
\hline
\end{tabular}

mažesnès nei 120 min trukmès vidutinio intensyvumo fizinis krūvis, pavyzdžiui, greitas ejjimas $5-7 \mathrm{~km} / \mathrm{val}$. greičiu ir 60 min trukmès didelio intensyvumo fizinis krūvis [17].

Studentų fizinis aktyvumas buvo vertinamas suskirstant studentus ị per mažai fiziškai aktyvius $(<150$ min per savaitę) ir pakankamai fiziškai aktyvius ( $\geq 150$ min per savaitę) pagal PSO 2011 $\mathrm{m}$. fizinio aktyvumo rekomendacijas 18-64 metų amžiaus grupès, ị kurią patenka ir studentai, asmenims. Antrosios amžiaus grupès fizinis aktyvumas apima aktyvią profesinę, namų ruošos bei laisvalaikio veiklą, važiavimą dviračiu, ejimą pèsčiomis, ịvairius žaidimus. Norint pagerinti širdies ir kraujagyslių, atramos ir judèjimo sistemų veiklą bei sumažinti lètinių neinfekcinių ligų riziką, šios amžiaus grupès žmonèms rekomenduojama ne mažiau nei 150 minučių per savaitę užsiimti aerobinị pajègumą ugdančia vidutinio intensyvumo fizine veikla [3]. Šioje klausimų dalyje buvo vertinama ir studentų fizinio aktyvumo vieta, tikslai bei sporto šakos, suklasifikuotos pagal atliekamo fizinio darbo trukmę, ugdomas ypatybes ir energijos gamybos organizme ypatumus treniruočių proceso metu (1 lentelè) [18].

Surinktų duomenų statistinè analizè atlikta naudojant statistinès analizès paketą IBM SPSS Statistics v. 22.0. Tolydžių duomenų charakteristikų apibūdinimams buvo skaičiuojamas vidurkis, standartinis nuokrypis (toliau - $\mathrm{SN}$ ). Kokybinių duomenų dažnis buvo vertinamas absoliučiais skaičiais ir procentais. Skirtumui tarp grupių nustatyti naudotas Pearson chi square $\left(\chi^{2}\right)$ suderinamumo kriterijus, o esant mažiau nei 5 tikètiniems dažniams - Fisher tikslusis testas. Statistinio reikšmingumo lygmuo buvo pasirinktas $\alpha=0,05$, o gauti rezultatai buvo laikomi statistiškai reikšmingais, kai paklaidos tikimybès reikšmè $\mathrm{p} \leq 0,05$. 


\section{Rezultatai}

Vykdant tyrimą, buvo apklausti 278 studentai, iš to skaičiaus: vyrų $-30,2$ proc., moteru - 69,8 procento. Amžius $20,83 \pm 1,68$ metų. VU studentai sudarè 69,4 proc., LEU - 30,6 procento Vidutinis studentų KMI 21,79 $\pm 2,76$. Mažesnis nei rekomenduojamas KMI nustatytas 9,4 proc., normalus $-78,8$ proc., o antsvoris $-11,2$ proc. studentų. Detalesnè tyrimo rezultatų analizè parodé, kad skirtinguose universitetuose studijuojančių vyrų ir moterų KMI skiriasi. Daugiau vyru KMI yra per didelis, palyginti su moterimis, kurių KMI dažniau per mažas. Tai patvirtina reikšmingas skirtumas tarp vyrų ir moteru KMI: 3,6 proc. vyrų ir 12 proc. moteru KMI buvo per mažas, atitinkamai 25 proc. vyrų ir 5,2 proc. moterų turèjo antsvorio $(\mathrm{p}<0,001)(2$ lentelè).

Tyrimo rezultatai parodè, kad 35,1 proc. studentų atlieka vidutinio sunkumo darbą, 27,9 proc. - labai lengvą ir lengvą darbą, 23,9 proc. - sunkų ir 13 proc. studentų atlieka labai sunku darbą. Daugiau nei pusè (58,3 proc.) sportuojančių respondentų kultivuoja sporto šakas, ugdančias greitumą ir jëgą, 20,6 proc. - ugdančias mišrų (aerobinị ir anaerobinị) pajejgumą ir 21,1 proc. - ugdančias aerobinị pajègumą.

Tik šiek tiek daugiau nei pusès (51,3 proc.) studentų fizinis aktyvumas yra pakankamas $(\geq 150$ min per savaitę). Visiškai nesportuoja 24,2 proc. studentų, 24,5 proc. per savaitę sportuoja tik 1-2 kartus, 31,4 proc. studentų per savaitę sportuoja 3-4 kartus (atitinka rekomendacijas) ir 19,9 proc. - 5-7 kartus.

Didžioji dalis (64,9 proc.) studentų dažniausiai sportuoja uždarose patalpose (sporto salèse, klubuose), 17,8 proc. - lauke, gryname ore ir 17,3 proc. - namuose. Pagrindinis sportuojančiu studentų ( 75,8 proc.) sportavimo tikslas yra pagerinti sveikatą ir savijautą (74,6 proc.). Ištvermès didinimą, kaip sportavimo tikslą, nurode 43,1 proc. respondentų. Jėgos ugdymą, kūno masės mažinimą ir raumenų masès didinimą, kaip sportavimo tikslą, nurodè atitinkamai 35,9 proc., 34,9 proc. ir 29,7 proc. sportuojančių studentų.

LEU studentų fizinis aktyvumas yra didesnis, palyginti su VU. VU studentu fizinis aktyvumas yra mažas (43,2 proc.) ir vidutinio sunkumo ( 38,5 proc.), o

2 lentelè. Respondentų apibūdinimas pagal lytị, amžių ir KMI

\begin{tabular}{|c|c|c|c|c|c|}
\hline \multirow{2}{*}{\multicolumn{2}{|c|}{ Požymis }} & \multicolumn{2}{|c|}{ VU } & \multicolumn{2}{|c|}{ LEU } \\
\hline & & \multirow{3}{*}{$\begin{array}{c}\text { abs. sk. } \\
34 \\
159\end{array}$} & \multirow{3}{*}{\begin{tabular}{|c|} 
proc. \\
17,6 \\
82,4
\end{tabular}} & \multirow{3}{*}{$\begin{array}{c}\text { abs. sk. } \\
50 \\
35\end{array}$} & \multirow{3}{*}{$\begin{array}{c}\text { proc. } \\
58,8 \\
41,2\end{array}$} \\
\hline \multirow{3}{*}{ Lytis } & Vyrai & & & & \\
\hline & Moterys & & & & \\
\hline & Iš viso & \multicolumn{2}{|c|}{193} & \multicolumn{2}{|c|}{85} \\
\hline \multirow{3}{*}{ Amžius (metais) } & Min & \multirow{2}{*}{\multicolumn{2}{|c|}{$\begin{array}{l}18 \\
32\end{array}$}} & \multicolumn{2}{|c|}{19} \\
\hline & Max & & & & \\
\hline & Vidurkis \pm SN & \multicolumn{2}{|c|}{$20,65 \pm 1,75$} & \multicolumn{2}{|c|}{$21,25 \pm 1,43$} \\
\hline \multirow{3}{*}{ KMI $\left(\mathbf{k g} / \mathbf{m}^{2}\right)$} & $<18,5$ & 24 & 12,6 & 2 & 2,4 \\
\hline & $18,5-24,99$ & 151 & 79,1 & 68 & 80,0 \\
\hline & $\geq 25$ & 16 & 8,4 & 15 & 17,6 \\
\hline
\end{tabular}

3 lentelè. VU ir LEU studentų fizinis aktyvumas

\begin{tabular}{|c|c|c|c|c|c|c|}
\hline \multirow{2}{*}{\multicolumn{2}{|c|}{ Požymis }} & \multicolumn{2}{|c|}{$\mathbf{V U}$} & \multicolumn{2}{|c|}{ LEU } & \multirow[b]{2}{*}{$\mathbf{P}$} \\
\hline & & \multirow{2}{*}{$\begin{array}{c}\text { abs. sk. } \\
74\end{array}$} & \multirow{2}{*}{\begin{tabular}{|l|} 
proc. \\
38,5
\end{tabular}} & \multirow{2}{*}{$\begin{array}{c}\begin{array}{c}\text { abs. } \\
\text { sk. }\end{array} \\
3\end{array}$} & \multirow{2}{*}{$\begin{array}{c}\text { proc. } \\
3,6\end{array}$} & \\
\hline \multirow{4}{*}{$\begin{array}{l}\text { Fizinio } \\
\text { aktyvumo } \\
\text { grupé }\end{array}$} & $\begin{array}{l}\text { I - labai lengvas ir lengvas } \\
\text { darbas }\end{array}$ & & & & & \multirow{4}{*}{$<0,001$} \\
\hline & $\begin{array}{l}\text { II - vidutinio sunkumo dar- } \\
\text { bas }\end{array}$ & 83 & 43,2 & 14 & 16,7 & \\
\hline & III - sunkus darbas & 28 & 14,6 & 38 & 45,2 & \\
\hline & IV - labai sunkus darbas & 7 & 3,6 & 29 & 34,5 & \\
\hline \multirow{4}{*}{$\begin{array}{l}\text { Sporta- } \\
\text { vimo kartų } \\
\text { skaičius } \\
\text { per savaitę }\end{array}$} & Nesportuoja & 67 & 34,7 & 0 & 0,0 & \multirow{4}{*}{$<0,001$} \\
\hline & $1-2$ kartai & 63 & 32,6 & 5 & 6,0 & \\
\hline & $3-4$ kartai & 49 & 25,4 & 38 & 45,2 & \\
\hline & $5-7$ kartai & 14 & 7,3 & 41 & 48,8 & \\
\hline \multirow{2}{*}{$\begin{array}{l}\text { Fizinio } \\
\text { aktyvumo } \\
\text { trukmė per } \\
\text { savaitę } \\
\end{array}$} & $<150$ min per savaitę & 88 & 71,0 & 16 & 19,3 & \multirow[b]{2}{*}{$<0,001$} \\
\hline & $\geq 150$ min per savaitę & 36 & 29,0 & 67 & 80,7 & \\
\hline \multirow{3}{*}{$\begin{array}{l}\text { Sporto } \\
\text { šakos, } \\
\text { ugdančios }\end{array}$} & Greitumą ir jègą & 55 & 47,8 & 61 & 72,6 & \multirow{3}{*}{0,001} \\
\hline & $\begin{array}{l}\text { Mišrų (aerobinị ir anaero- } \\
\text { binị) pajègumą }\end{array}$ & 27 & 23,5 & 14 & 16,7 & \\
\hline & Aerobini pajègumą & 33 & 28,7 & 9 & 10,7 & \\
\hline \multirow{3}{*}{$\begin{array}{l}\text { Sportavimo } \\
\text { vieta }\end{array}$} & Lauke, gryname ore & 18 & 15,3 & 15 & 22,4 & \multirow{3}{*}{0,002} \\
\hline & Uždarose patalpose & 71 & 60,2 & 49 & 73,1 & \\
\hline & Namuose & 29 & 24,6 & 3 & 4,5 & \\
\hline \multirow{5}{*}{$\begin{array}{l}\text { Sportavimo } \\
\text { tikslas }\end{array}$} & Pagerinti sveikatą, savijautą & 96 & 77,4 & 60 & 70,6 & 0,265 \\
\hline & Sumažinti kūno masę & 52 & 41,9 & 21 & 24,7 & 0,010 \\
\hline & Išugdyti jëgą & 37 & 29,8 & 38 & 44,7 & 0,028 \\
\hline & Padidinti ištvermę & 47 & 37,9 & 43 & 50,6 & 0,069 \\
\hline & Padidinti raumenų masę & 30 & 24,2 & 32 & 37,6 & 0,036 \\
\hline
\end{tabular}


LEU studentų fizinis aktyvumas dažniau yra didelis (45,2 proc.) ir labai didelis $(34,5$ proc.) $(\mathrm{p}<0,001)$. VU studentai dažniau nei LEU kultivuoja mišrų (aerobinị ir anaerobini $)(23,5$ proc. ir 16,7 proc.) ir aerobini ( 28,7 proc. ir 10,7 proc.) pajègumus ugdančias sporto šakas $(\mathrm{p}=0,001)$. Išaiškinta ir tai, kad LEU studentai, palyginti su VU, dažniau sportuoja 3-4 kartus per savaitę $(45,2$ proc. ir 25,4 proc., $\mathrm{p}<0,001)$, jų fizinio aktyvumo trukmė dažniau atitinka PSO rekomenduojamą ( $\geq 150 \mathrm{~min}$ per savaitę) (71 proc. ir 19,3 proc., $\mathrm{p}<0,001$ ), jie dažniau sportuoja lauke, gryname ore

4 lentelè. Respondentų fizinis aktyvumas (vyrai ir moterys)

\begin{tabular}{|c|c|c|c|c|c|c|}
\hline \multirow{2}{*}{\multicolumn{2}{|c|}{ Požymis }} & \multicolumn{2}{|c|}{ Vyrai } & \multicolumn{2}{|c|}{ Moterys } & \multirow[b]{2}{*}{$\mathbf{p}$} \\
\hline & & $\begin{array}{c}\text { abs. } \\
\text { sk. }\end{array}$ & proc. & $\begin{array}{l}\text { abs. } \\
\text { sk. }\end{array}$ & proc. & \\
\hline \multirow{4}{*}{$\begin{array}{l}\text { Fizinio akty- } \\
\text { vumo grupé }\end{array}$} & $\begin{array}{l}\text { I - labai lengvas ir lengvas } \\
\text { darbas }\end{array}$ & 16 & 19,0 & 61 & 31,8 & \multirow{4}{*}{$<0,001$} \\
\hline & $\begin{array}{l}\text { II - vidutinio sunkumo dar- } \\
\text { bas }\end{array}$ & 15 & 17,9 & 82 & 42,7 & \\
\hline & III - sunkus darbas & 29 & 34,5 & 37 & 19,3 & \\
\hline & IV - labai sunkus darbas & 24 & 28,6 & 12 & 6,3 & \\
\hline \multirow{4}{*}{$\begin{array}{l}\text { Sporta- } \\
\text { vimo kartų } \\
\text { skaičius per } \\
\text { savaitę }\end{array}$} & Nesportuoja & 8 & 9,6 & 59 & 30,4 & \multirow{4}{*}{$<0,001$} \\
\hline & $1-2$ kartai & 13 & 15,7 & 55 & 28,4 & \\
\hline & 3 - 4 kartai & 34 & 41,0 & 53 & 27,3 & \\
\hline & 5-7 kartai & 28 & 33,7 & 27 & 13,9 & \\
\hline \multirow{2}{*}{$\begin{array}{l}\text { Fizinio akty- } \\
\text { vumo trukmè } \\
\text { per savaitę }\end{array}$} & $<150$ min per savaitę & 24 & 32,9 & 80 & 59,7 & \multirow[b]{2}{*}{$<0,001$} \\
\hline & $\geq 150$ min per savaitę & 49 & 67,1 & 54 & 40,3 & \\
\hline \multirow{3}{*}{$\begin{array}{l}\text { Sporto šakos, } \\
\text { ugdančios: }\end{array}$} & Greitumą ir jègą & 57 & 77,0 & 59 & 47,2 & \multirow{3}{*}{$<0,001$} \\
\hline & $\begin{array}{l}\text { Mišrų (aerobinį ir anaerobini } \\
\text { pajegumą) }\end{array}$ & 8 & 10,8 & 33 & 26,4 & \\
\hline & Aerobini pajègumą & 9 & 12,2 & 33 & 26,4 & \\
\hline \multirow{3}{*}{$\begin{array}{l}\text { Sportavimo } \\
\text { vieta }\end{array}$} & Lauke, gryname ore & 17 & 25,4 & 16 & 13,6 & \multirow{3}{*}{0,023} \\
\hline & Uždarose patalpose & 44 & 65,7 & 76 & 64,4 & \\
\hline & Namuose & 6 & 9,0 & 26 & 22,0 & \\
\hline \multirow{5}{*}{$\begin{array}{l}\text { Sportavimo } \\
\text { tikslas }\end{array}$} & Pagerinti sveikatą, savijautą & 57 & 76,0 & 99 & 73,9 & 0,736 \\
\hline & Sumažinti kūno masę & 14 & 18,7 & 59 & 44,0 & $<0,001$ \\
\hline & Išugdyti jëgą & 35 & 46,7 & 40 & 29,9 & 0,015 \\
\hline & Padidinti ištvermę & 31 & 41,3 & 59 & 44,0 & 0,706 \\
\hline & Padidinti raumenų masę & 33 & 44,0 & 29 & 21,6 & 0,001 \\
\hline
\end{tabular}

5 lentelè. Studentų pasiskirstymas pagal sporto šakas ir sportavimo tikslus

\begin{tabular}{|c|c|c|c|c|c|c|c|}
\hline \multirow{3}{*}{ Sportavimo tikslas } & \multicolumn{6}{|c|}{ Sporto šakos, ugdančios: } & \multirow{3}{*}{$\mathbf{p}$} \\
\hline & \multicolumn{2}{|c|}{$\begin{array}{c}\text { greitumą ir } \\
\text { jègą }\end{array}$} & \multicolumn{2}{|c|}{$\begin{array}{c}\text { mišrų (aerobini } \\
\text { ir anaerobinị) } \\
\text { pajėgumą }\end{array}$} & \multicolumn{2}{|c|}{$\begin{array}{c}\text { aerobini } \\
\text { pajègumą }\end{array}$} & \\
\hline & abs. sk. & proc. & abs. sk. & proc. & abs. sk. & proc. & \\
\hline Pagerinti sveikatą, savijautą & 85 & 58,2 & 30 & 20,5 & 31 & 21,2 & 0,966 \\
\hline Sumažinti kūno masę & 41 & 61,2 & 11 & 16,4 & 15 & 22,4 & 0,548 \\
\hline Išugdyti jëgą & 56 & 78,9 & 9 & 12,7 & 6 & 8,5 & $<0,001$ \\
\hline Padidinti ištvermę & 57 & 65,5 & 17 & 19,5 & 13 & 14,9 & 0,131 \\
\hline Padidinti raumenų masę & 44 & 72,1 & 8 & 13,1 & 9 & 14,8 & 0,031 \\
\hline
\end{tabular}

$(22,4$ proc. ir 15,3 proc., $\mathrm{p}=0,002)$. VU studentai, palyginti su LEU, dažniau sportuoja, kad sumažintų kūno masę ( 41,9 proc. ir 24,7 proc., $\mathrm{p}=$ $0,01)$. LEU studentai, dažniau nei $\mathrm{VU}$, sporto treniruotes skiria jẻgos ugdymui (44,7 proc. ir 29,8 proc., $p$ $=0,028)$. Daugiau LEU (37,6 proc.) nei VU (24,2 proc.) studentų sportavimo tikslas yra raumenų masès didinimas $(p=0,036)$ (3 lentelè).

Tyrimo duomenimis, vyrų fizinis aktyvumas yra didesnis, negu moterų. 34,5 proc. ir 28,6 proc. vyru fizinis aktyvumas yra sunkus ir labai sunkus. Moteru priešingai, fizinis aktyvumas dažniau yra mažas $(31,8$ proc.) ir vidutinio sunkumo $(42,7$ proc.).

Vyrai, dažniau nei moterys, kultivuoja greitumą ir jègą ugdančias sporto šakas ( 77 proc. ir 47,2 proc.), o moterys, dažniau nei vyrai, renkasi sporto šakas, ugdančias mišrų (aerobini ir anaerobinį) (26,4 proc. ir 10,8 proc.) ir aerobini pajègumą (26,4 proc. ir 12,2 proc.) $(\mathrm{p}<0,001)$. Nustatyta, kad vyrai palyginti su moterimis, dažniau sportuoja 3-4 kartus per savaitę (41 proc. ir 27,3 proc., $p$ $<0,001)$, jų fizinio aktyvumo trukmé dažniau atitinka PSO rekomenduojamą $(\geq 150$ min per savaitę) $(67,1$ proc. ir 40,3 proc., $\mathrm{p}<0,001)$. Vyrai, dažniau nei moterys, sportuoja lauke, gryname ore $(25,4$ proc. ir 13,6 proc.). Moterys, dažniau nei vyrai, sportuoja namuose (22 proc. ir 9 proc.) $(\mathrm{p}=0,023)$. Moterys, palyginti su vyrais, dažniau sportuoja tam, kad sumažintų kūno masę (atitinkamai 44 proc. ir 8,7 proc., $p<0,001$ ), o vyrai, palyginti su moterimis, dažniau sportuoja norèdami išugdyti jègą (46,7 proc. ir 29,9 proc., $\mathrm{p}=0,015)$ ir padidinti raumenų masę (44,0 proc. ir 21,6 proc., $p=0,001$ ) (4 lentelè). Nustatyta, kad 85 proc. nesportuojančių studentų neturi tam laiko. 10 proc. studentų yra nemotyvuoti, 5 proc. 


\section{4}

negali sportuoti dèl finansinès padèties.

Studentai, kurių sportavimo tikslas yra išugdyti jègą, dažniau renkasi greitumą ir jègą (78,9 proc.), nei mišrų (aerobinį ir anaerobinị) ar aerobinị pajègumus ugdančias sporto šakas $(12,7$ proc. ir 8,5 proc.) $(\mathrm{p}<0,001)$. Greitumą ir jègą ugdančias sporto šakas dažniau ( 72,1 proc.), nei mišrų (aerobinị ir anaerobinị) ir aerobinị pajejgumus ugdančias sporto šakas (13,1 proc. ir 14,8 proc.), renkasi studentai, kurių tikslas padidinti raumenų masę $(\mathrm{p}=0,031)$ (5 lentelè).

\section{Rezultatų aptarimas}

Didesnio intensyvumo fizinis aktyvumas naudingesnis sveikatai - sumažeja rizika susirgti lètinèmis neinfekcinėmis ligomis, pavyzdžiui, pakankamas fizinis aktyvumas ( $\geq 150$ min per savaitę) mažina tikimybę susirgti cukriniu diabetu (14 proc.), širdies ir kraujagyslių sistemos (16 proc.), onkologinèmis (3 proc.) ir lètinèmis neinfekcinèmis ligomis [1].

Lietuvoje $[4,5]$ ir kitose šalyse [6-12] atliktų tyrimu duomenimis, studentų fizinis aktyvumas yra mažesnis, nei rekomenduoja PSO $(<150$ min per savaitę). Tokie pat rezultatai buvo gauti atlikus mūsų tyrimą. Beveik pusès $(48,7$ proc.) studentų fizinis aktyvumas yra per mažas. Išryškejjo skirtumai, priklausomi nuo mokymosi ịstaigos ir lyties: LEU studentų fizinis aktyvumas yra didesnis, palyginti su VU, vyrai labiau fiziškai aktyvūs, nei moterys. Analogiškai ir kitose šalyse - vyrai labiau fiziškai aktyvūs, nei moterys [6-12]. Vertinant studentų fizini aktyvumą skirtingose mokymosi ịstaigose, svarbu tai, kad LEU, skirtingai nei VU, fizinis aktyvumas yra ịtrauktas ị paskaitų tvarkaraščius. Fizinį aktyvumą skatinančių dalykų nebuvimas paskaitų tvarkaraščiuose yra svarbus fizinį aktyvumą ribojantis veiksnys.

Esminès Lietuvos $[5,14]$ ir kitų šalių $[6,11]$ studentų nepakankamo fizinio aktyvumo priežastys yra laiko trūkumas ir motyvacijos stoka. Analogiškai mūsų tyrimo metu pagrindinè studentų nepakankamo fizinio aktyvumo priežastis buvo laiko trūkumas ( 85 proc.). Būtina akcentuoti, kad visi nesportuojantys studentai yra iš VU, kur biomedicinos sričių mokslai yra įtempti, reikalaujantys daug laiko, todèl tai galèjo daryti poveikị mūsų tyrimo rezultatams.

Apibendrinant studentų fizinio aktyvumo duomenis, galima konstatuoti, kad Lietuvos aukštujų mokyklų studentų fizinis aktyvumas yra per mažas. Išskirtinai ị nepakankamo fizinio aktyvumo grupę patenka VU studentai, ypač moterys, todèl perspektyvoje būtų racionalu ị paskaitų tvarkaraščius įtraukti privalomąsias kūno kultūros pratybas, sudaryti palankesnes sąlygas studentų aktyviam laisvalaikio leidimui (įrengti žaidimų aikšteles, taikyti nuolaidas mokamoms sporto paslaugoms), ugdyti sveikos gyvensenos ịgūdžius ir didinti motyvaciją užsiimti aktyvia fizine veikla, kartu suteikiant kuo daugiau kompetentingos informacijos apie fizinio aktyvumo naudą.

\section{Išvados}

1. Didžiosios dalies (78,8 proc.) Lietuvos aukštuju mokyklų studentų kūno masès indeksas yra normalus, antsvoris būdingas tik kas dešimtam studentui (vyrui), o nepakankama kūno masè - kas dešimtai studentei (moteriai).

2. Dauguma studentų atlieka lengvą arba vidutinio sunkumo darbą. Nors esminis sportuojančių studentų tikslas yra sveikatos ir savijautos gerinimas, tačiau beveik pusès studentu ( 48,7 proc.) fizinis aktyvumas yra nepakankamas (<150 min per savaitę). Nepakankamą studentų fizinį aktyvumą iš esmès lemia laiko trūkumas, rečiau - nepakankama motyvacija ir finansine padètis.

3. Studentų fizinị aktyvumą lemia mokymosi ịstaiga ir lytis. Lietuvos edukologijos universiteto studentai labiau fiziškai aktyvūs, palyginti su Vilniaus universiteto studentais. Vyrai labiau fiziškai aktyvūs, dažniau atlieka sunkų ir labai sunkų darbą, kultivuodami greitumą ir jègą ugdančias sporto šakas. I nepakankamo fizinio aktyvumo grupę patenka Vilniaus universiteto studentès (moterys).

4. Didžioji dalis $(64,9$ proc.) studentų dažniausiai sportuoja uždarose patalpose (sporto salėse, klubuose), per retai lauke, gryname ore.

\section{Literatūra}

1. Kyu HH, Bachman VF, Alexander LT, Mumford JE, Afshin A, Estep K, et al. Physical activity and risk of breast cancer, colon cancer, diabetes, ischemic heart disease, and ischemic stroke events: systematic review and dose-response meta-analysis for the global burden of disease study 2013. BMJ 2016;354:i3857. https://doi.org/10.1136/bmj.i3857

2. Aktas N, Ozdogan Y. A study of the state of knowing the nutritional literacy concept in Turkey. Researchers World 2016;7(2):46. https://doi.org/10.18843/rwjasc/v7i2/04

3. WHO. Global recommendations on physical activity for health. Geneva 2010.

4. Strazdienė N., Adaškevičienė E. Studentų sveikatą stiprinantis fizinis aktyvumas, jo raiška laisvalaikiu. Tiltai, 2014;61(4):93104.

5. Stukas R., Dobrovolskij V., Adomaitis S. Visuomenės sveikatos studentų gyvensena ir fizinis aktyvumas. Sporto mokslas, 2012;4(70):50-5.

6. Moreno-Gómez C, Romaguera-Bosch D, Tauler-Riera P, Bennasar-Veny M, Pericas-Beltran J, Martinez-Andreu S, et al. Clustering of lifestyle factors in Spanish university students: the relationship between smoking, alcohol consumption, physical activity and diet quality. Public Health Nutrition 2012;15(11):2131-9.

https://doi.org/10.1017/S1368980012000080 
7. Zaccagni L, Masotti S, Donati R, Mazzoni G, Gualdi-Russo E. Body image and weight perceptions in relation to actual measurements by means of a new index and level of physical activity in Italian university students. Journal of Translational Medicine 2014;12(1):42.

https://doi.org/10.1186/1479-5876-12-42

8. Breitenbach Z, Raposa B, Szabó Z, Polyák É, Szücs Z, Kubányi J, et al. Examination of Hungarian college students' eating habits, physical activity and body composition. European Journal of Integrative Medicine 2016;8:13-7.

https://doi.org/10.1016/j.eujim.2016.11.007

9. El Ansari W, Stock C, Mikolajczyk RT. Relationships between food consumption and living arrangements among university students in four European countries-a cross-sectional study. Nutrition Journal 2012;11(1):28. https://doi.org/10.1186/1475-2891-11-28

10. Yahia N, Wang D, Rapley M, Dey R. Assessment of weight status, dietary habits and beliefs, physical activity, and nutritional knowledge among university students. Perspectives in Public Health 2016;136(4):231-44. https://doi.org/10.1177/1757913915609945

11. Majeed F. Association of BMI with diet and physical activity of female medical students at the university of Dammam, Kingdom of Saudi Arabia. Journal of Taibah University Medical Sciences. 2015;10(2):188-96.

https://doi.org/10.1016/j.jtumed.2014.11.004

12. Hamam FA, Eldalo AS, Alnofeie AA, Alghamdi WY, Almutairi SS, Badyan FS. The association of eating habits and lifestyle with overweight and obesity among health sciences students in Taif University, KSA. Journal of Taibah University Medical Sciences 2017;12(3): 249-260.

https://doi.org/10.1016/j.jtumed.2016.12.001

13. Dobrovolskij V, Stukas R. Lietuvos aukštųų universitetinių mokyklų studentų fizinio aktyvumo ypatumai. Visuomenès sveikata. 2015;1:22-30.

14. Norkus A, Alūzas R. Studentų sveikatos ugdymas Lietuvos aukštosiose mokyklose: galimybès ir problemos. Studijos šiuolaikinèje visuomenèje. Mokslo darbai, 2012;3(1):185-193.

15. Merkys G., Norkus A., Dovydaitis J. Lietuvos studentų mitybos ịpročiai ir juos sąlygojantys veiksniai: Masinės apklausos rezultatai. Sveikatos mokslai, 2016;26(6):5-12.

https://doi.org/10.5200/sm-hs.2016.084
16. WHO. Global database on body mass index, BMI 2017.

17. Lietuvos Respublikos sveikatos apsaugos ministro $2016 \mathrm{~m}$. birželio 23 d. įsakymas Nr. V-836 "Dèl Lietuvos Respublikos sveikatos apsaugos ministro 1999 m. lapkričio 25 d. įsakymo Nr. 510 "Dèl rekomenduojamų paros maistinių medžiagų ir energijos normų tvirtinimo" pakeitimo". https://e-seimas. lrs.lt/portal/legalAct/lt/TAD/5c9fd5c042ed11e68f45bcf65e0a 17ee?jfwid=10az821tc2

18. Skernevičius J., Milašius K., Raslanas A., Dadelienė R. Sporto treniruotè. Monografija. Vilnius, 2011:431.

\section{PHYSICAL ACTIVITY OF LITHUANIAN HIGHER EDUCATION STUDENTS AND ITS DETERMINANTS M. Baranauskas, R. Arlauskas, R. Stukas, J.A. Abaravičius, T. Martinkutè}

Keywords: students, physical activity, body mass index, public health.

Summary

The internationally established links between good health and adequate physical activity are undeniable. Life expectancy can be reduced and chronic illnesses may increase due to lack of physical activity and obesity. Therefore, regular monitoring of physical activity is necessary. The aim of the study was to determine the student body mass index, physical activity and its determinants. During the study, 278 students aged $20.83 \pm 1.68$ years were interviewed. Students were surveyed using the questionnaire survey method. The results of the study showed that every tenth male student was overweight and every tenth female student was underweight. Improving health is an essential goal for students in sports. $48.7 \%$ of students are physically inactive (training time is less than 150 min per week). The lack of time is the key to undersporting. Female students of Vilnius University fall into the group of insufficient physical activity. The majority (64.9\%) of students exercise indoors (in gyms, clubs), but too few students engage in physical activity outdoors in the open air. In the future, it would be sensible to include mandatory physical education exercises in the lecture schedules. It is also necessary to develop students' healthy lifestyle skills and motivation to engage in active physical activity.

Correspondence to: marius.baranauskas9@gmail.com

Gauta 2020-02-04 